\title{
Effect of Leptin Gene Polymorphism on Fattening and Slaughter Value of Line 990 Gilts
}

\author{
Dorota Stępień-Poleszak, Arkadiusz Pietruszka, Maria Kawęcka \\ Department of Pig Breeding, Agricultural University of Szczecin, Szczecin, Poland
}

Received June 23, 2008

Accepted February 9, 2009

\begin{abstract}
The study was aimed at defining leptin gene polymorphism and its potential association with values of particular features of fattening and slaughter value of gilts of Line 990 . The study included a total of 208 gilts. The polymorphic locus in $L E P$ gene was identified by the restriction enzyme Hinfl in 3469 position, by using the polymerase chain reaction-restriction fragment-length polymorphism (PCR-RFLP) method. Two alleles of LEP gene were identified: T (0.94) and C (0.06), resulting in two genotypes: TC (0.12) and TT (0.88). We did not observe any gilts of CC genotype. The analysis of values of fattening and slaughter features, depending on $L E P$ genotype did not reveal significant differences in body mass increase, daily gain from day 63 to 180, and daily gain from birth to day 180 , feed conversion per $1 \mathrm{~kg}$ body mass and the loin-eye thickness. Significant differences between the $L E P$ genotypes were present for such features as the backfat thickness at points $\mathrm{P} 2(p \leq 0.05)$ and $\mathrm{P} 4$ $(p \leq 0.01)$ and average backfat thickness $(p \leq 0.01)$ in favour of TT genotype. We noted higher average values of lean meat content in carcass in favour of TT homozygotes, compared to the heterozygotes $(p \leq 0.05)$. The investigation contributes additonal information regarding $L E P$ gene polymorphism in gilts of Line 990 . Knowledge of $L E P$ genotypes may be useful to improve the slaughter value in gilts primarily due to less fatness. Due to the lack of individuals representing CC genotype in our results, research should continue on a larger population.
\end{abstract}

Genotype, gilts, LEP, fattening, slaughter traits

Identification of genes responsible for the formation of fattening and slaughter features is important for the breeders and producers of livestock, because it allows reaching faster selection response. Lately, the breeding programmes in Poland have been using the first molecular test, which allows selection of animals depending on the gene of rianodine receptor $(R Y R 1)$. One of the priorities of the pork production industry is the decrease of carcass fatness; therefore it seems purposeful to seek the molecular basis allowing the segregation of individuals meeting the desired requirements.

Leptin is a protein hormone, being the product of LEP gene, commonly known as obesity gene (Zhang et al. 1994). This protein belongs to the cytokine family, together with the growth hormone and prolactin receptor (Houseknecht et al. 1998). Leptin is produced mainly by adipocytes, which form the adipose tissue (Harigaya et al. 1997) and also by brain, heart, placenta, stomach wall and some neoplasms (Barb 1999).

The wide spectrum of leptin activity suggests its potential influence on a range of utility features, important from the economic point of view. First of all, leptin is known as a factor regulating the energy demand of the organism through stimulation and inhibition of appetite. It influences the growth and development of different types of cells. Leptin plays an important role in maturation of the organism, and also in regulating its immunity.

Leptin, influencing the energetic demand and feed conversion, frames the level of body fat, and affects the values of fattening and slaughter indicators in livestock (Houseknecht et al. 1998). In pigs, leptin consists of 167 amino-acids, of molecular mass $18,661 \mathrm{kDa}$ (Bidwell et al. 1997). The leptin gene shows high homology of sequences in different species. It consists of 3 exons and 2 intrones, which allows assuming that this protein's functions as well as the mechanism of action are similar for the laboratory animals, breeding animals and human beings. In pigs, LEP gene is localized on chromosome 18 in q 1.3 - q 2.1 position (Neuenschwander et al. 1996). In porcine leptin, several single 
mutations have been detected so far, (Stratil et al. 1997; Kennes et al. 2001), with the use of polymerase chain reaction-restriction fragment-length polymorphism (PCR-RFLP). The best described polymorphism of the leptin gene in swine is a single mutation of exon III T3469C, detected with the use of Hinfl enzyme (Stratil et al. 1997).

Due to the lack of unambiguous conclusions concerning the role of polymorphism of $L E P$ gene in the formation of utility features in livestock, we carried out research on gilts of Line 990 in order to specify polymorphism of LEP gene and its potential association with particular fattening and slaughter features.

\section{Materials and Methods}

The study included a total of 208 gilts of Line 990 from the Zootechnic Plant of Pawlowice, property of the Institute of Animal Production of Krakow. The gilts originated from hyperprolific sows. Data concerning the fattening and slaughter value were collected based on breeding documentation. On the $180^{\text {th }}$ day of life gilts were evaluated for their fattening and slaughter value. The fattening value was assessed based on the daily gain expressed in daily body weight increases, feed conversion per kilogram of the body weight increase. The feed conversion was calculated as the amount of diet consumed during the test (from the $63^{\text {th }}$ to the $180^{\text {th }}$ day of life) and divided by the increase of body mass throughout that time. During the examination time the gilts were kept in uniform environmental conditions and fed individually with a special mixed fodder, according to the Polish feeding norms (Polish Norm of Pigs Nutrition 1993).

The lean meat content was evaluated with the use of ultrasound apparatus PIGLOG 105. In order to do that, the backfat thickness was measured at two points: $\mathrm{P} 2$ - between the $13^{\text {th }}$ and $14^{\text {th }}$ thoracic vertebra $-3 \mathrm{~cm}$ and $\mathrm{P} 4-8$ $\mathrm{cm}$ on the right side from the central line of the back, and, in the same place, every second measurement of backfat thickness - the loin eye thickness - point P4M.

Based on the above examination, we obtained the results concerning the following indicators: body weight on the $21,28,63$ and 180 day, daily gain from birth to the $180^{\text {th }}$ day, the increase of body weight from 63 to 180 day of life, feed conversion, backfat thickness at points: $\mathrm{P} 2$ and $\mathrm{P} 4$, average backfat thickness from points $\mathrm{P} 2$ and $\mathrm{P} 4$, the loin eye thickness, lean meat content, index of performance test. Based on the above results we have calculated the selection indexes for evaluated gilts.

In order to specify the influence of leptin on some specific fattening and slaughter features, we identified the polymorphism of exon III leptin gene, position 3469, substitution of $\mathrm{T} \rightarrow \mathrm{C}$.

The first stage consisted of extracted genomic DNA from the full peripheral blood, with the use of Master PureTM DNA Purification Kit of Epicentra Technologies ${ }^{\circledR}$. The amplification of DNA fragments was carried out with the use of PCR reaction, where primer sequences reported by Neuenschwander et al. (1996) were used. Primer sequences were as follows: Forward: 5'-TGC AGT CTG TCT CCT CCA AA-3'; reverse: 5'- CGA TAA TTG GAT CAC ATT TC TG-3'. The reaction mixture consisted of: $70 \mathrm{ng}$ genomic DNA, 10 pmol of each primer, $0.2 \mathrm{mmol}$ of each dNTP, $1.5 \mathrm{mmol} \mathrm{MgCl}_{2}$ and $0.5 \mathrm{IU}$ of Taq DNA polymerase (MBI Fermentas Burlington, Ontario, Canada) in a standard PCR buffer, the entire reaction mixture was filled up with demineralized water up to the final volume of $20 \mu$. The thermal conditions for PCR including denaturation $95^{\circ} \mathrm{C} / 3 \mathrm{~min}$ followed by 33 cycles: denaturation $95{ }^{\circ} \mathrm{C} / 40 \mathrm{~s}$, annealing $55^{\circ} \mathrm{C} / 1 \mathrm{~min}$, synthesis of products: $72{ }^{\circ} \mathrm{C} / 1 \mathrm{~min}$, final extension 72 ${ }^{\circ} \mathrm{C} / 5 \mathrm{~min}$. PCR products were digested with $5 \mathrm{U}$ of restriction enzyme Hinfl at $37{ }^{\circ} \mathrm{C}$ during 4 h. The restriction fragments were examined by electrophoresis in $3 \%$ agarose gel stained with $1 \times \mathrm{TBE}$ buffer and ethidiumbromide. The last stage was the visualization of digested DNA fragments using UV rays. The PCR-RFLP assay yielded a single 152 -bp band (genotype TT) and three bands for the genotype TC- 68 bp, 84 bp, $152 \mathrm{bp}$.

Based on the above results, the statistic calculations were carried out, using the double factor analysis of variation. The significance of differences between the groups was calculated based on Duncan's multiple test. The computer package Statistica $6.0 \mathrm{pl}$ was used for calculation.

The following equation was used:

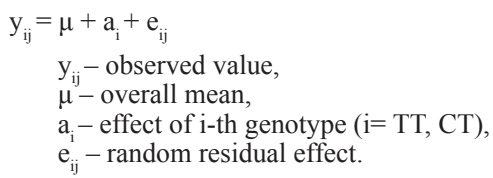

\section{Results}

In the examined gilts population, Line 990 two LEP alleles, $\mathrm{C}$ and $\mathrm{T}$, were identified. The occurrence of two out of three possible genotypes was observed: TC and TT. Allele $\mathrm{T}$ appeared with a frequency of 0.94 , while allele $\mathrm{C}$ with a frequency of 0.06 . Most of the gilts had the TT genotype (0.88), and heterozygotes appeared with a frequency of 0.12 . No gilt with $\mathrm{CC}$ genotype was identified (Table 1). 
Table 1. The frequency of $L E P$ genotypes and alleles

\begin{tabular}{|l|c|c|c|c|c|}
\hline \multirow{4}{*}{} & \multicolumn{5}{|c|}{ LEP } \\
\cline { 2 - 6 } & \multicolumn{3}{|c|}{ Genotype } & T & C \\
\cline { 2 - 6 } & TT & TC & CC & & 0.06 \\
\hline Number & 184 & 24 & - & 0.94 & 0.04 \\
\hline Frequency & 0.88 & 0.12 & - & & Allele \\
\hline
\end{tabular}

Table 2. Effect of $L E P$ genotypes on average value of analyzed traits

\begin{tabular}{|c|c|c|c|c|c|}
\hline \multirow{4}{*}{ Trait } & \multicolumn{4}{|c|}{ Genotype $L E P$} & \multirow{4}{*}{ Coefficient $\mathrm{F}$} \\
\hline & \multirow{2}{*}{\multicolumn{2}{|c|}{$\begin{array}{c}\mathrm{TT} \\
\mathrm{n}=184\end{array}$}} & \multirow{2}{*}{\multicolumn{2}{|c|}{$\begin{array}{c}\mathrm{TC} \\
\mathrm{n}=24\end{array}$}} & \\
\hline & & & & & \\
\hline & $\bar{x}$ & $\mathrm{~s}$ & $\overline{\bar{x}}$ & $\mathrm{~s}$ & \\
\hline Body weight at 21 days $[\mathrm{kg}]$ & 5.74 & 0.07 & 5.77 & 0.16 & 0.021 \\
\hline Body weight at 28 days [kg] & 7.61 & 0.09 & 7.52 & 0.27 & 0.10 \\
\hline Body weight at 63 days [kg] & 19.95 & 0.23 & 18.79 & 0.59 & 2.97 \\
\hline Body weight at 180 days [kg] & 102.4 & 0.44 & 103.5 & 1.31 & 0.73 \\
\hline Daily gain from birth to 180 days [g] & 570 & 2.50 & 577 & 7.61 & 0.71 \\
\hline Daily gain from 63 to 180 days [g] & 709 & 3.97 & 727 & 11.40 & 2.58 \\
\hline Feed conversion per $1 \mathrm{~kg}$ body weight $[\mathrm{kg}]$ & 2.88 & 0.16 & 2.79 & 0.04 & 3.71 \\
\hline Backfat thickness at P2 [mm] & 11 & 0.16 & 12 & 0.58 & $4.55^{*}$ \\
\hline Backfat thickness at P4 [mm] & 9 & 0.14 & 11 & 0.59 & $14.17 * *$ \\
\hline Average backfat thickness [mm] & 10 & 0.13 & 11.5 & 0.54 & $14.35^{* *}$ \\
\hline Loin eye thickness [mm] & 52.7 & 0.41 & 54.1 & 1.44 & 1.33 \\
\hline Lean meat content $[\%]$ & 59.12 & 0.14 & 58.29 & 0.47 & $3.97^{*}$ \\
\hline Selection index & 126 & 0.65 & 124 & 1.89 & 1.0 \\
\hline
\end{tabular}

* significance level $p \leq 0.05$

$* *$ significance level $p \leq 0.01$

Based on the results of examination we assumed regarding the daily gain of body weight from the $63^{\text {th }}$ to the $180^{\text {th }}$ day and daily gain of body weight from birth to the $180^{\text {th }}$ day that the TC heterozygotes had slightly higher values compared to TT homozygotes (Table 2). However, the differences between the genotypes were not significant. Concerning the feed conversion per $1 \mathrm{~kg}$ of body weight gain, we did not find significant differences between the $L E P$ genotypes.

A higher average backfat thickness was detected in TC heterozygotes compared to TT homozygotes. The differences in favour of TT genotype were significant $(p \leq 0.01)$. We also found significant differences of backfat thickness measured at P2 point $(p \leq 0.05)$ and at P4 point $(p \leq 0.01)$. Hence, the gilts of TC genotype were fattier compared to TT homozygotes. Gilts with TC genotype had a little thicker loin muscle than the ones of TT genotype, however, the differences were not significant. The lean meat content in carcass was higher in homozygotes TT compared to individuals of heterozygotic genotype. In this case the differences were significant $(p \leq 0.05)$.

\section{Discussion}

A similar frequency of genotypes, with small occurrence of CC genotype and distinct predominance of TT homozygotes was the result of studies on the Line 990 pigs of Korwin-Kossakowska et al. (2002). Quite similar results of studies were obtained also by Křenková et al. (1999), where in the examined population of sows resulting from 
the crossing of Landrace with Large White breed and Pietrain with Large White, the TT genotype occurred with the frequency of 0.85 . However, the $\mathrm{CC}$ homozygotes were not identified. The low frequency of homozygotes with $\mathrm{C}$ allele to the level of 0.15 was detected in the studies of Kulig et al. (2001), where TT genotype appeared up to the level of 0.76 and showed to be the predominant genotype. Low frequency of $\mathrm{C}$ allele in Duroc, Yorkshire and Landrace also resulted from the research of Kennes et al. (2001). However, Stratil et al. (1997) obtained different results. The analysis of frequency of occurrence of particular alleles of LEP gene was carried out by those authors with the use of Meishan breed, which is commonly known to be one of the most fertile pigs. They did not detect the appearance of $\mathrm{T}$ allele, and all of the individuals were CC homozygotes. In the representatives of different breeds (Large White, Black Pied Přeštice, Piètrain) and Czech meat pig, a distinct predominance of T allele is observed, which varies around the level of 0.83 (Stratil et al. 1997). The studies of Kurył et al. (2003) with the use of Pietrain, Zlotnicka Spotted, Landrace and line Torhyb, Stamboek as well as line PIC, found low participation of $\mathrm{C}$ allele in all of the representatives of examined breeds and lines. The CC genotype appeared only in the Landrace breed, and its frequency was 0.07 . The TT genotype appeared as the predominant one in the representatives of all the breeds and lines. More recent studies of Szydłowski et al. (2004) and Blicharski et al. (2004) confirm the low frequency of $\mathrm{C}$ allele in pigs and the predominance of TT genotype in the examined swine population of the following breeds: Polish Large White, Polish Landrace and Line 990. One of the latest studies concerning gilts resulting from the crossing of Polish Large White and Polish Landrace reports the frequency of CC, TC and TT genotypes of the values of $0.02,0.18$ and 0.80 , respectively (Terman 2005). Therefore, the results of studies concerning the frequency of appearance of particular genotypes consent with the general tendency occurring in different breeds and lines of upgrading swine.

The studies of Kulig et al. (2001) aimed at analyzing differences between the particular genotypes of $L E P$ concerning fattening and slaughter value and were performed on the pigs of Polish Landrace. They found a higher daily gain of individuals with CC genotype compared to the TT homozygotes $(p \leq 0.05)$. In the studies of Blicharski et al. (2004) performed on Polish Large White pigs, the highest daily gain was detected in CC genotype gilts. The daily gain was positively correlated with fatness; therefore the individuals of CC genotype were the ones with the highest daily gain and the highest fatness. Kennes et al. (2001) obtained different results, where the TT genotype individuals grew faster $(p \leq 0.05)$.

The results of the above study concerning the average backfat thickness and backfat thickness measured at points P2 and P4 are similar to the results of Kurył et al. (2003). The authors found in the representatives of the PIC line a lower content of fat in TT individuals compared to the individuals of TC genotype. One of the first studies concerning the influence of LEP gene polymorphism on the fat content in swine conducted by Jiang and Gibson (1999) suggested an association between C allele and obtaining thinner lard. However, those results did not give any definite answer, because the following experiments did not find significant differences between the particular genotypes. The results of Kennes et al. (2001) are similar to the results of this study, where the occurrence of C allele correlates with the existence of thicker lard. The research of Blicharski et al. (2004) found the highest fatness among the individuals with CC genotype of Polish Large White breed, which is compatible with the results of this study on gilts of Line 990.

Concerning the lean meat content in carcass, Kulig et al. (2001) obtained different results. In studies on Polish Landrace pigs, the authors found a lower content of meat among the TT homozygotic individuals compared to heterozygotes $(p \leq 0.05)$. However, complex studies conducted by Kurył et al. (2003) found significantly higher $(p \leq 0.05)$ lean meat content in individuals with TT genotype compared to TC heterozygotes, which is 
compatible to the results of this study. Szydłowski et al. (2004) received different results while analyzing gilts of the following breeds: Polish Large White, Polish Landrace and Line 990. Those authors found similar growth, level of fat content, and feed conversion irrespective of leptin genotype, without any significant differences.

Based on the conducted studies we have found significant differences between the genotypes, especially concerning the backfat thickness. It might be a proof a potential connection between the polymorphism of leptin gene and the level of fatness of Line 990 gilts. Moreover, we have found a connection between the LEP genotype and lean meat content in carcass $(p \leq 0.05)$, which may be partially caused by the effect of thinning backfat thickness in TT genotype individuals compared to the TC heterozygotes.

Differentiation of LEP genotype resulting in lower frequency of the occurrence of $\mathrm{C}$ allele among the population is connected with the appearance of excessive fattening and consequently with the lowering of meat content. Therefore a low frequency of $\mathrm{C}$ allele seems to be the result of appropriate selection aimed at receiving desired changes in swine fattening. The final effect is that the individuals have lower fat content and higher meat content. Thus, the information concerning $L E P$ gene expression in pig selection seems to be justified.

However, considering some differences between the results of this study and results of different authors, studies on a larger population of animals should be continued, in order to verify the final conclusions concerning the influence of $L E P$ gene polymorphism to the features connected with the meat and fat content in gilts.

\section{Vliv polymorfismu genu pro leptin na př́růstky a jatečnou výtěžnost prasniček Line 990}

Cílem studia bylo definovat polymorfismus genu pro leptin a jeho potenciální spojitost s hodnotami přírůstků a jatečnou výtěžností prasniček Line 990. Studium zahrnovalo celkem 208 prasniček. Polymorfní lokus v LEP genu byl identifikován s využitím restrikčního enzymu Hinfl v 3469. pozici pomocí polymerázové řetězcové reakce, využívající rozdílnost $\mathrm{v}$ délce restrikčních fragmentů (PCR-RFLP). U LEP genu byly identifikovány 2 alely: T (0.94) a C (0.06), mající za následek dva genotypy: TC (0.12) a TT (0.88). Genotyp CC nebyl u žádné ze sledovaných prasniček prokázán. Zjištěné hodnoty váhových př́růstků a jatečné výtěžnosti v závislosti na genotypu v LEP genu neodhalily průkazné rozdíly, denní hmotnostní př́růstek mezi 63. a 180. dnem a v době od narození do 180 . dne se významně nelišil, podobně jako konverze krmiva na $1 \mathrm{~kg}$ živé hmotnosti a výška pečeně. Prưkazné rozdíly v závislosti na genotypu v tomto genu byly prezentovány v př́padě tloušt’ky hřbetního tuku v místě P2 $(p \leq 0.05)$ a $\mathrm{P} 4(p \leq 0.01)$ ve prospěch TT genotypu. Vyšších hodnot dosahovala u TT homozygotů i průměrná tloušt'ka hřbetního tuku $(p \leq 0.01)$. Vyšší průměrné hodnoty $\mathrm{v}$ obsahu libové svaloviny u poražených kusů patřících dle genotypu v LEP genu k homozygotům TT ve srovnání s heterozygoty $(p \leq 0.05)$ nebyly nalezeny.

\section{References}

Barb C 1999: The brain - pituitary - adipocyte axis: Role of leptin in modulating neuroendocrine function. J Anim Sci 77: $1249-1257$

Bidwell C, Ji S, Frnk G, Cornelius S, Willis G, Spurlock M 1997: Cloning and expression of the porcine obese gene. Anim Biotechnol 8: 136-142

Blicharski T., Kurył J., Pierzchała M. (2004): Relationship between polymorphism at loci colipase and leptin and most important fattening and slaughter traits in pigs with special reference to intramuscular fat - a review. $\mathrm{Pr}$ Mat Zoot- Zesz Spec 15: 41-46 (in Polish)

Harigaya A, Nagashima K, Nako Y, Morikawa A 1997: Relationship between concentration of serum leptin and fetal growth. J Clin Endocrinol Metab 82: 3281-3284

Houseknecht K, Baile C, Matteri R, Spurlock M 1998: The biology of leptin: a review. J Anim Sci 76: $1405-1420$ 
Jiang Z, Gibson J 1999: Genetic polymorphism in the leptin gene and their association with fatness in four pig breeds. Mamm Genome 10: 191-193

Kennes Y, Murphy B, Pothier F, Palin M 2001: Characterization of swine leptin (LEP) polymorphisms and their association with production traits. Anim Genet 32: 215-218

Korwin-Kossakowska A, Kamyczek M, Cieślak D, Pierzchała M, Kurył J 2002: The effect of the polymorphism of leptin (LEP), leptin receptor (LEPR) and osteopontin (OPN) genes on selected reproduction traits of synthetic Line 990 sows. Anim Sci Pap Rep 20: 159-168

Křenková L, Kuciel J, Urban T 1999: Association of the RYR1, GH, LEP and TF genes with carcass and meat quality traits in pigs. Czech J Anim Sci 44: 481-486

Kulig H, Grzesiak W, Szatkowska I 2001: Effect of leptin gene polymorphism on growth and carcass traits in pigs. Arch Tierz-Arch Anim Breed 44: 291-296

Kurył J, Kapelański W, Pierzchała M, Bocian M, Grajewska S 2003: A relationship between genotypes at the GH and LEP loci and carcass meat and fat deposition in pigs. Anim Sci Pap Rep 21: 15-26

Neuenschwander S, Rottenberger G, Meijerink E, Jorg H, Strznzinger G 1996: Partial characterization of porcine obesity gene (OBS) and its localization to chromosome 18 by somatic cell hybrids. J Anim Sci 78: 275-278

Polish norm 1993: Polish norm of pigs nutrition 1993 (Normy żywienia świń). Instytut Fizijologii i żywienia zwierząt PAN, Jabłonna (in Polish), pp. 1-87

Stratil A, Peelman L, Van Poucke M, Cepica S 1997: A HinfI PCR-RFLP at the porcine leptin (LEP) gene. Anim Genet 28: 371-372

Szydłowski M, Stachowiak M, Maćkowski M, Kamyczek M, Eckert R, Różycki M, Świtoński M 2004: No major effect of the leptin gene polymorphism on porcine production traits. J Anim Breed Genet 121: 149-155

Terman A 2005: Effect of the polymorphism of prolactin receptor (PRLR) and leptin (LEP) genes on the litter size in Polish pigs. J Anim Breed Genet 122: 400-404

Zhang Y, Proenca R, Maffei M, Barone M, Leopold L, Friedman J 1994: Positional cloning of the mouse obese gene and its human homologue. Nature 372: 425-43 